\title{
Combating 9/11 Negative Images of Arabs in American Culture: A Study of Yussef El Guindi's Drama
}

\author{
Mahmoud F. Alshetawi ${ }^{1}$ \\ The University of Jordan
}

\begin{abstract}
This study intends to examine the dramatic endeavours of Arab American playwrights to make their voices heard through drama, performance, and theatre in light of transnationalism and diaspora theory. The study argues that Arab American dramatists and theatre groups attempt to counter the hegemonic polemics against Arabs and Muslims, which have madly become characteristic of contemporary American literature and media following 9/11. In this context, this study examines Yussef El Guindi, an Egyptian-American, and his work. El Guindi has devoted most of his plays to fight the stereotypes that are persistently attributed to Arabs and Muslims, and his drama presents issues relating to identity formation and what this formation means to be Arab American. A scrutiny of these plays shows that El Guindi has dealt with an assortment of topics and issues all relating to the stereotypes of Arab Americans and the Middle East. These issues include racial profiling and surveillance, stereotypes of Arabs and Muslims in the cinema and theatre, and acculturation and clash of cultures.
\end{abstract}

Keywords: acculturation, Arab American, diaspora, drama, identity formation, racial profiling, stereotypes theatre.

Over the ages, Arabs and Muslims have been denigrated and stereotypically represented in almost all outlets of Western media: the cinema, literature and the press and other channels of expression. From the Middle Ages to the present day, Arabs and Muslims have been the subject of ridicule and a target of condemnation as enemies of the West and what it stands for. Islam has been viewed as a perennial adversary to the West, and Arabs have been indiscriminately portrayed as backward, sensuous, and violent, lacking restraint and self-control (Daniel, 2009). These stereotypes have survived throughout ages with varying degrees of intensity. However, the image of Arabs and Muslims as terrorists and villains worsened in the aftermath of the post-9/11 terrorist attacks on the Twin Towers of New York simply because they were associated ethnically and religiously with the hijackers of the airplanes that hit the Twin Towers (Arjana, 2015).

Consequently, Arabs and Islam have interchangeably become the subject of suspicion and targets of attack of all sorts. Attributes such as terrorism, violence, and extremism are attached to Arabs, and Islam as faith and culture is viewed with fear and awe. Arabs and Muslims living in Western countries and the United States have found themselves at an impasse as they struggle to dispel the stereotypes that they are harboring violence and hatred towards their host countries, and that Islam and terrorism are two sides of the same coin. These attacks have been particularly damaging to the image of Arab Americans who bear the brunt of the 9/11 backlash. Therefore, Arab-American writers work hard to counter the anti-Arab, anti-Islamic discourse through various

${ }^{1}$ Corresponding Author E-mail: alshetawi_m@ju.edu.jo 
media venues, and to combat the accusations hurled at Arabs and Muslims as terrorists or harboring terrorism (Bakalian \& Bozorgmehr, 2009).

Western media have portrayed Arab Americans and Muslims as enemies from within, and consequently, they have become targets of animosity and abuse. They are indiscriminately lumped together with the terrorists and unjustly profiled on racial and religious grounds (Alsultany, 2012). The post-9/11 era has witnessed a surge of American literature that delineates Arabs and Muslims negatively and promotes Islamophobia. Indeed, a large body of literature, fiction, drama and poetry, produced post-9/11 associated Arabs and Islam with terrorism and hate (Keniston \& Quinn, 2008). For example, John Updike's Terrorist (2006) and Don Delillo's Falling Man (2007) illustrate the negative delineations of Arabs and Muslims in the contemporary American novel.

At the same time, a steady growth of what could be termed Arab American literature has occurred in both the United States and Britain to counter the surge of Islamophobia in these countries. Carol Fadda-Conrey (2014) has commented on this issue as follows:

The past two and a half decades have witnessed an exciting flourishing of Arab-American literature, as made evident by the rapid increase in the number of literary texts published in an array of genres, including fiction, poetry, nonfiction, and drama. ... Yet this increased interest in the current production and circulation of Arab-American literary texts is ironically paralleled by a prevalent and tenacious bias against Arabs and Muslims, one that often erroneously portrays their long presence in the US not only as a recent phenomenon but as a dangerous and unwelcome one to boot (p. 1).

Notably, Arab American literature, in general, is quite new in the American literary scene (Salaita, 2007; Majaj, 2008; Hassan, 2011).

\section{The Rise of Arab American Drama and Theatre}

Post-9/11 has also witnessed the birth and proliferation of Arab-American drama and theatre. Arab-American playwrights have joined efforts to counter the growing dangers of Islamophobia, and the onslaughts on their identity as Arab Americans and fight racial profiling. Before 9/11 Arab American drama was sporadic and inconsistent in the sense that there was a relative absence of Arab American theatre or playwrights who made their voices heard across the United States. However, after 9/11 the American theatre scene witnessed a surge of Arab American drama and theatre that aimed at addressing the American audience across the board to voice the concerns and anxieties of Arab Americans. Arab American writers begin to speak up and raise their voices through drama and theatre and the cinema as well as other literary outlets especially poetry and the novel. They want to dispel much of the stereotype attributes which have been wrongly associated with them because of the 9/11 terrorist attacks (Basiouny \& Carlson, 2009; Najjar, 2014).

This study examines the efforts of Arab American playwrights to make their voices heard through drama, performance and theatre in light of transnationalism and diaspora theory (Bauböck \& Faist, 2010). The study argues that Arab American dramatists and theatre groups push back against the hegemonic polemics directed at Arabs and Muslims, which has become characteristic of contemporary American literature and media following 9/11. Viewed in light of the anti-Arab American literary discourse, Arab American playwrights and performers have made giant strides in changing the stereotypes of Arabs in general and countering the loud voices of those who try to 
add fuel to the blazing flames of Islamophobia. They use the stage as a platform to reach out to the different strata of the American public to make their voices heard. Therefore, Post-9/11 Arab American drama and theatre is politically oriented to address the living concerns and anxieties of Arab Americans and those of their home countries in the Middle East.

The issues addressed in Arab-American drama and theatre can be summarized as follows. First, Arab American playwrights and artists assert in their plays and performances their identity as American citizens like other immigrant minorities like Jews, Chinese, or Latinos; therefore, they reject racial profiling and discrimination based on race, ethnicity or religion resulting from the tragic events of 9/11. Second, Arab-American dramatists and artists realize that the media especially Hollywood, theatre and other venues of visual arts have contributed to the defamation of Arabs and Muslims in the United States and created accounts of villainous Arab characters who are associated with terrorism and violence against America and the West in general. Third, ArabAmerican playwrights realize that the Arab-Israeli conflict has been a catalyst in clouding the relationship between the Arabs and the West, especially the United States. This political issue and its ensuing consequences on the attitudes towards Arab Americans have been taken up in many Arab-American plays. Finally, Arab-American dramatists have commonly dramatized the clash of cultures in their plays and theatre performances by exposing on the stage the predicaments of Arab immigrants. These dramatizations have examined the conflict between first generation immigrants and their US-born children and the throes of acculturation and assimilation into a new homeland, which is inimical to their presence, and gazes at them as aliens (Doguas, 2020; Soyer, 2019).

These themes have been generally reflected in the plays and workshops of a host of ArabAmerican playwrights such as Yussef El Guindi, Sami Younis, Ismail Khaledi, Betty Shamieh, Leila Buck, Heather Raffo, Lameece Issaq and Jacob Kader, Jamal Khoury and others. What is quite interesting about the movement of Arab-American theatre in the United States is that it has been well received across the country by the American audience. Their plays and performances have been fortunate to find theatre companies and playhouses willing to host them such as Golden Thread Productions, Silk Road Rising, Nibras and other Arab American theatre groups that have espoused the cause of Arab Americans and helped introduce minority drama and theatre to the public (Hill, 2009; Najjar, 2014, 2015). This is perhaps unprecedented because historically the plays of Arab American playwrights before 9/11 were often sporadically hosted at diverse staging platforms and community theatres, and they were hardly heard of on a wide scale.

Nonetheless, except for Arab American-playwright Yussef El Guindi, Arab-American drama remains relatively meagre compared to the corpus of plays by other American minority playwrights such as Latinos and African American or Asian American drama. Besides, the literary criticism of the plays and the reviews written on their stage productions remain scanty and insufficient, sporadically published in major US newspapers and some other literary outlets (Smith, 2006). Small as it might be, the corpus of Arab-American drama is a testimony of the vibrant American theatre that allows for voices against the mainstream to be heard. Arab-American playwrights have put Arabic culture on the American stage, and, by doing so, they offer the American audience a humane image of Arabs and Arab culture that has been misrepresented and denigrated for decades.

Yussef El Guindi has made his voice heard loud and clear in countering the stereotypes of Arab Americans in post-9/11 media outlets and literary productions. He has devoted most of his plays to fighting the stereotypes that are persistently attributed to Arabs and Muslims, and his drama presents issues relating to identity formation and what it means to be Arab American (Kan, 2008). In his essay "Rosencrantz and Guildenstern meet Abdallah and Ahmad: Musings about 
Arabs and Muslims in American Theater," which is a kind of a manifesto on the representation of Arabs and Muslims in American theatre and visual arts, El Guindi (2019) states:

Repeatedly. Every year. In every decade of my life, Arabs and Muslims have been headline news in some capacity or other (almost in a negative light). ... So that Arabs and Muslims end up always coming across as genetically prone to mindless violence, wars, the oppression of women, etc. The go-to images always being large mobs of angry Arab men, veiled women, menacing bearded men in prayer, bombed sites, and so on (pp. 312-313).

These are the stereotypes that El Guindi has been fighting in almost all of his plays that are analyzed in this paper. This paper reviews six of his plays that illustrate the themes that are commonly treated in his drama at large. These plays are Back of the Throat (2005), Language Rooms (2010), Jihad Jones and the Kalashnikov Babes (2008), Our Enemies: Lively Scenes of Love and Combat (2008), Threesome (2015) and Ten Acrobats in an Amazing Leap of Faith (2005). A scrutiny of these plays shows that El Guindi has dealt with an assortment of topics and issues all relating to the existing stereotypes of Arab Americans and the Middle East in American culture.

These issues include: 1)- profiling and surveillance; 2)- discrimination at the workplace; 3)- identity formation and assimilation; 4)- family disintegration; and 5)- acculturation, and the clash of cultures. Moreover, El Guindi and other fellow Arab-American playwrights have brought onto the stage the social upheavals and violence in their home countries as a result of the American invasion of Iraq in 2003, the War on Terror, the despotism of local regimes, and the Arab Spring. Indeed, many Arab-American dramatists have depicted the suffering of the ordinary man in Middle Eastern countries and the hardships ensuing from the tyrannies of Mideast regimes supported by the US government and the West at large. While these issues are interrelated and often overlap, it would be convenient to consider them under three major headings: racial profiling and persecution, stereotypes of Arabs in the cinema and theatre and acculturation and clash of cultures.

\section{Racial Profiling and Persecution}

One major issue that El Guindi tackles in his drama is profiling and persecution of Arabs in the aftermath of 9/11 attacks. As a result of the public hysteria following the attacks, ArabAmerican citizens were put under surveillance and they were often interrogated by the FBI and other government agencies. In their book Backlash 9/11: Middle Eastern and Muslim Americans Respond, Anny Bakalian and Mehdi Bozorgmehr (2009) commented on the situation as follows:

Tuesday, September 11, 2001, stands as one of the darkest days in modern U. S. history. It will be long remembered by the millions of Americans who witnessed the collapse of the Twin Towers over and over on their television screens. For Middle Eastern and Muslim Americans, '9/11' likewise signifies a shocking and sad day, but it also marks the beginning of a new era in which they became the victims of backlash. For many, the tragic events ushered in a period of hate crimes, profiling, and discrimination. Though stereotypes and discriminatory actions were not new to these minorities, the pos-9/11 backlash was overwhelming and relentless (p. 1). 
This is the kind of poisoned climate that El Guindi dramatizes in his plays Back of the Throat and Language Rooms. El Guindi brings up this issue on the stage to make the American public aware of the racial violations of the constitutional rights of Arab-Americans as US citizens who are falsely condemned for engaging in terrorist activities simply because they are Arabs and Muslims.

Commenting on the genesis of Back of the Throat, El Guindi explains why he undertook to write this play especially in light of the Patriot Act which was signed into law by President George W. Bush in 2001. El Guindi states:

Back of the Throat began as a paranoid thought game. In those first few months after 9/11 as an Arab/Muslim-American one wasn't quite sure where one stood. What laws were still in place to protect one from government inquisitiveness or from a government, rightly or wrongly, deciding to throw aside civil liberty concerns in the need to protect the country from an amorphous enemy whose potential for another strike was very real. In this climate, where one feared officials needing to look and act tough and avoid allowing more terrorists through the net, I personally, on a visceral level, found myself fearing a knock on the door. For no logical reason, I should add (cited in Kan, 2008, p. 2).

El-Guindi has dealt with this issue in at least two of his plays, Back of the Throat and Language Rooms.

El-Guindi's play Back of the Throat has been fairly discussed in a good number of academic studies, which this paper documents. (See, Mohammed, 2011; Lacko, 2013; Fadda-Corney, 2014; Najjar, 2014; Ali, 2017; Alqahtani, 2018). The play was first produced by Golden Thread Productions in San Francisco, California, in 2005 and then toured the United States. It was staged at different theatres and playhouses at different American cities including the Silk Road Rising in Chicago in 2006. The play toured many American cities and was well received, which is evident in the positive reviews of the play. Understandably the play is a product of post- 9/11 situation in America vis-à-vis the political persecutions and profiling of Arabs and Muslims living in the United States. Back of the Throat reflects the dilemma of Arabs in the United States El Guindi suggested, who said: "The Patriot Act came in, and suddenly you didn't know what your rights were. You started hearing these stories of people getting stopped for what they were reading at airports, of the F.B.I going to galleries and questioning the artist if the exhibit was politically charged" (cited in Smith, 2006).

A brief summary of the play is perhaps relevant to make the analysis clear. What seems to be a routine visit to Khaled's home turns out to be a traumatic experience and a grilling interrogation. Khaled is an Egyptian US-born citizen who has no other home but the United States. True his parents were Egyptian immigrants, but Khaled has no place to turn to except his home country, America. Khaled, the protagonist of the play, is like millions of hyphenated Americans of colour who are born and raised in the country. They do not know their countries of origin, and for US-born nationals, the United States is their home country. While sitting at home enjoying his privacy and secluded life, two government agents call upon him. What seems at the beginning to be a normal social call turns into a messy interrogation, and Khaled's sense of security is completely shattered. He is accused of having a connection with an Islamic terrorist group that intends to mete havoc at an American monument. The two government agents, probably FBI agents, tell Khaled that this is going to be a routine visit to ask him a few questions and clarify 
certain issues. In the beginning, Khaled is fully cooperative and even courteous, and he tells them that he has nothing to hide.

Khaled believes in America and what it stands for, and he thinks what makes America different from other countries is the rule of law and the rights of citizenship which every American enjoys regardless to his origin, race, the color of skin or religion. However, as the interrogation proceeds, he realizes that he has no such rights because he was an American citizen. On the contrary, Khaled, perhaps like millions of immigrants will lose almost all the privileges accrued to him due to his citizenship and the accusations of conspiracy and links with anti-American terrorist groups are readily made up to be thrown upon him and his kind.

El Guindi creates an atmosphere of fear, anxiety and menace, which was quite popular in the literature of the mid-twentieth century when the world lived under the shadow of communism, fascist regimes and the threat of a nuclear war that was looming. Indeed, the play is reminiscent of the early drama of Harold Pinter, especially his plays The Room and The Birthday Party. Critics have dubbed Pinter's early drama as the drama of menace in which the peace and security of an individual or a home are suddenly invaded by an outside force, and his/her life is disrupted for unknown reasons. This is also reminiscent of Kafka in such works as The Trial and other narratives that convey the anxiety, fear and persecution of the individual that a mysterious authority or power caused in a realistic and often surrealistic style.

The two government agents, Bartlett and Carl, begin their inspection of Khaled's apartment quite normally looking here and there for something they do not declare at the beginning. They even try to pronounce Khaled's name, which they find difficult because the letter " $\dot{\tau}-\mathrm{kh}$ " does not exist in English. Bartlett tries to pronounce the name sometimes "Kaled" and other times "Haled". Carl, whom we understand has served in some capacity (probably in the US army or as a CIA agent) in the Middle East, has pronounced the name correctly. The title of the play comes from Bartlett's statement "It's that back of the throat thing" (p. 13). The two agents begin prying into the private life of Khaled. They ask him how he could live without a TV and how he spends his free time. Normally, Khaled takes these inquiries easily, and he has shown full cooperation with the two agents. Of course, Khaled has books on various subjects, including politics and culture and even pornographic materials.

As the interrogation proceeds and the two inspectors become more demanding and personal, Khaled begins to feel irritated. He knows that he has nothing to hide and he tells the agents if they are looking for something, or they want to know something in specific then he begs them to say it. It seems that the agents are following certain vetting procedures that delve deeply into the psyche of the person under interrogation. When Khaled reminds the agents of his rights as an American citizen, they get upset and threatening. In response to Khaled's "I know my rights," Bartlett blares out: "What do you have is the right to cooperate with your intelligence and do the right thing and asking for a lawyer is a dumb move because it alerts me to a guilt you may be trying to hide" (p. 20). Bartlett's tone and attitude change into one more threatening and insulting.

Having realized that he is pushed into the corner and is being accused of a serious crime or offence, Khaled acts normally like any ordinary American in such circumstances and asks them gently to leave his place and that he needs a lawyer to be with him. He is denied the exercise of his constitutional rights simply because he is the son of immigrants. Khaled says: "I have rights. (Slight beat.) I do have rights" (p. 22). However, Bartlett replies that what they are doing has nothing to do with ethnicity or racial profiling:

One more thing: At no time should you think this is an ethnic thing. Your ethnicity has nothing to do with it other than the fact that your background happens to be the place where most of this crap is coming 
from. So naturally, the focus is going to be on you. It's not profiling; it's deduction. You're a Muslim and an Arab (p. 23).

Bartlett has said it all in his comments that Khaled is being interrogated because he is an Arab and a Muslim, and he comes from the Middle East from which most hijackers came. Bartlett's speech sums up the whole story of anti-Arab sentiments embodied in the broad practices of ethnic profiling and racial persecution practiced mainly on Arab-American citizens following the 9/11 attacks.

Khaled has repeatedly asked them about his crimes if any, and he does not understand why he is treated this way. He says: "But I haven't done anything and you're acting like I have, what have I done?" (p. 24) He insists over and again that he has committed no crime to be treated in this way. He inquires: "You haven't told me what I've been accused of!" (p. 25) As Bartlett increasingly turns violent and abusive, Khaled reminds them that he is like them, an American, and that America is his home country. Khaled shouts out, "This is my country too, you know" (p. 25). And later he adds "This is still America and I will not be treated this way!" (p. 25) Khaled's resistance does not make Bartlett happy; on the contrary, he is so irritated by Khaled's insistence on his rights as a US citizen that Bartlett becomes very abusive and verbally violent. Bartlett says: "... if I hear you say "this is still America" one more time I am going to throw up. I will open your mouth and hurl a projectile of my burgher down your scrawny throat" (p. 25).

El Guindi sums up all sorts of abuses that Arab and Muslim immigrants would be subjected to on American streets or by US officials interrogating suspect terrorists in this play. For example, when Khaled insists on his constitutional rights as a US citizen Bartlett is so incensed that he hurls verbal obscenities upon Khaled. Bartlett says: "If I hear another immigrant spew back to me shit about rights, I will fucking vomit...You come here with shit, from shit countries. ..." (p. 26). His aggressive mood builds, and blinded by anger upon hearing Khaled speak of his rights as a citizen, Bartlett berates all immigrant discourse by denying them the rights to be equal as white US citizens. Bartlett: "It's galling. - Sticks in my craw. To hear these people who got here two hours ago quote back to me Thomas Jefferson and the Founding Fathers. They're not his fucking Fathers" (p. 26).

Carl, who turns out to be more vicious and violent than Bartlett, tries to ease the situation a little bit by reminding his colleague, Bartlett, that once an immigrant, like Khaled, has become a US citizen, then the Founding Fathers become his as well. This kind of discourse intends to educate the US public that all American citizens are equal regardless of their origin, ethnicities, and race. It is also suggestive of the fact that America is essentially an immigrant country and that the diversity of its citizens is a source of pride and strength. Having realized that he has gone too far in his tirade against immigrants, Bartlett tones down and says that he is not against immigrants as such. He even adds that immigrants have their contribution to making America what it is for they work hard to make homes and keep their families. Bartlett merely reflects what some top American officials have said against immigrants.

It is evident that the government agents have already dug up Khaled' s private life and now they are using this information as a weapon to press him to cough up any plot that he could be hatching. For example, Carl confronts Khaled with a photo showing him in a strip club as evidence of his perverted character. At this point in the play, El Guindi is using surrealistic elements by conjuring up people who are connected with Khaled in one way or another. For example, Carl talks about Asfoor and the librarian, Shelly. Perhaps the government agents are using these characters to frighten Khaled into believing that they know everything about him; therefore, he should not try to hide any information or evade their questions. It seems that the government agency has received information from some source that Khaled was involved in a plot or conspiracy against the country. 
In the aftermath of the 9/11, paranoia gripped America, and every Arab American or Muslim became a prime suspect.

The play suggests that Asfoor had recently entered the United States. He does not know English; therefore, he is looking for an Arab American like him to teach him English. Asfoor is from Egypt, and Khaled is originally from the same country. Being born in the United States and having never travelled abroad, Khaled does not know Arabic and he does not speak the language. The connection between the two men is the library, which is the best place for them to meet and where they have met. Shelly, the librarian, has her own suspicions about them and being driven by the anti-Arab media or perhaps anti-foreigner discourse, she has got a false feeling that they are suspicious characters, especially because she feels that Khaled has attempted to harass her. Beth, Khaled's ex-girlfriend, has a grudge against him. It seems that she has informed on him as well. In her testimony against him, she indicates that he is of a dubious character, sort of a fishy man. She accuses him of being excited or "gloating" about the terrorist attacks on New York. She even adds that Khaled has almost defended the attackers or even praised them. This testimony is enough to indict him or to make him a prime suspect.

El Guindi draws up a scene in which Khaled and his girlfriend Beth were discussing the Twin Towers attacks. Khaled was trying to look into the reason those terrorists attacked America. He brought politics into the problem thereby suggesting that the US policy in the Middle East was probably the cause for what happened. While he was no doubt condemning the terrorist attacks, he was as well critical of the US policies in the Middle East. The relation between Khaled and his girlfriend was not good, and they did have their quarrels. At first, she thought perhaps he had an affair with another woman, but after the attacks and his ambivalent response to them she became convinced that he was somehow connected with the attackers. Having seen him with a stranger, Asfoor, she became convinced that he had connections with a clandestine terror network. Therefore, she alerted the FBI to this new danger. El Guindi suggests that Arab Americans would be suspected to have inimical sentiments towards the United States for several reasons; someone might inform on you if you are not on good terms with them.

Throughout the whole interrogation which takes over than an hour, Khaled has not confessed to any crimes and the government agents have found no evidence of anything wrong. And yet he is severely punished for no apparent reason other than he is originally an Arab, and it is his bad luck to be caught up during the campaign against terrorism. El Guindi reveals in his haunting play the vetting procedures that are used to investigate terrorist activities. What he describes in the play is probably the iceberg of the protocols used to coerce suspects to cough up information. Khaled has been tortured and physically grilled to confess crimes that he has never committed.

As the interrogation proceeds, the government interrogators turn vicious and abusive. They have pried into his private life and personal belongings. They have exposed his shame by showing the things that he would like to keep secret because they are too personal and private such as his sexual fantasies, the porno magazine, and his visits to the strip club. They have used very abusive language towards him and immigrants in general. They have attacked Khaled physically. For example, Carl kicks him hard in the groin, making him lose his balance and fall on his knees writhing in pain. Worse than that Carl kneels on Khaled's chest and almost suffocates him. Ironically, Carl tells Khaled that he is to blame for making him hit him hard because he refuses to cooperate.

The most humiliating thing they have done to Khaled is to strip him of his clothes and underwear and pry into his private parts in case he is hiding some cryptic messages. The following excerpt tells it all about the vetting procedures that are followed in such cases. Bartlett: "Here's where I have to pry a little more than I like to. Can we- look at your peckers?" (p. 49) El Guindi 
has meticulously described the scene in which Khaled is immobilized, and his trousers are pulled down. Heedless to his painful cries, Bartlett puts on a latex glove and looks into Khaled's privates exposing his shame and making him feel that he is dirt. Having found nothing but a birthmark, Bartlett slaps him on the thigh, and tells him that they have not yet finished with him. If he has something to tell them, then he has to fill in the form they give him, and he knows where to find them. Khaled has shown resilience and endurance in absorbing all pressures put upon him to prove his innocence. After all, he has insisted upon his innocence, and his case highlights the stereotypical notions attached to Arab and Muslim Americans.

El Guindi presents the dilemma of every Arab American who would be considered guilty until he proves his innocence in Back of the Throat. El Guindi pursues the projection of Arabs as terrorist suspects in his play Language Rooms that was first performed in 2010. This dramatic piece may be considered as a sequel or perhaps a companion to Back of the Throat in the sense that it continues to portray the persecution of Arabs and Muslims under the name of fighting Islamic terrorism. Perhaps instigated by the Guantanamo detention center that was established in 2002 by the George W. Bush's administration during the War on Terror and the Abu Ghraib prison treatment of prisoners during the American occupation of Iraq, El Guindi sets his play at a black site, referring to the CIA secret prisons in which Arab and Muslim suspects are incarcerated indefinitely. The play delineates the torture, both psychological and physical, to which the prisoners are subjected. Being written after Back of the Throat, Language Rooms continues the same theme by taking the audience to utterly traumatic situation in which Arab American suspects of terrorism are detained and interrogated. Before the end of their interrogation of Khaled at his apartment in Back of the Throat, Bartlett tells Khaled that the interrogation is not over; they want him to think it over for they will be coming back to continue their case. In the meantime, Khaled has to fill in a form for when they return.

The play presents four characters, namely, two Arab-American cooperatives, Ahmed and Nasser, and their superintendent, Kevin, an African American citizen. There is also the nameless supervisor whose presence is much felt but who is never visible. The other character is Samir, an Arab (Egyptian) American who is being interrogated for his possible connection with a terrorist leader, Imam Al Rawi, a runaway that the CIA is hunting. Language Rooms begins where Back of the Throat ends; Khaled is probably detained at this facility, and Ahmed is investigating his case. Though Khaled does not appear in person throughout the play, we are made aware that Ahmed has interrogated him, and his dossier is very much referred to in Act One of the play.

Nasser: ... . We have to fit in. Do you understand? (Then) And if Kevin asks-, Look, if he asks about your interrogation of Khaled. Never mind (p. 141).

Indeed, later Kevin brings up the case of Khaled and Ahmed's work on it:

Kevin: ... .Your interrogations of Khaled was remarkable. The way you won him over, spoke his language. That is how you do it (p. 146).

However, it seems that Ahmed's interrogation of Khaled has made him a suspect himself. The question of Ahmed being sympathetic with Khaled pops up again and again and this is explained in conjunction with other things that made Ahmed not as loyal as he should be to America. Kevin asks Ahmed to look over Khaled's folder and the transcripts of his translations, 
and to be prepared to answer any further questions about what it could be his sympathy with Khaled:

Kevin: Oh. (Gets the folder referred to earlier.) The Khaled transcript. Look it over. Just to bring closure. (Hands him the folder.) And I'll ask that the supervisor how those damn things in the box are supposed to help us (p. 151).

Here, he refers to the scuba suit that will be used later to isolate Ahmed and put him into a physical situation whereby he will re-examine his loyalty and faith to his new country, the United States.

The play deals with a common theme which El Guindi has treated in his plays, namely identity and Islamophobia. In Back of the Throat, Khaled insists that he is truly an American and that America is his home; he reiterates that he has no other home but the United States. However, the two government agents, Carl and Bartlett, would never accept him on equal footing as a naturalborn US citizen simply because he is immigrant, thus suggesting that all immigrants are not to be trusted and their loyalty should be under surveillance. El Guindi pursues the same theme in Language Rooms in which two Arab-American citizens, Ahmed and Nasser, work for a government agency as translators-cum-interrogators. They are being employed for this agency because they speak Arabic; this means that the detainees are Arabs, hence the need for translators speaking Arabic. Again, in this play, El Guindi deals with the question of loyalty; Ahmed, who has been serving this agency, has become a suspect whose loyalty to the United States is being questioned. Like Khaled in Back of the Throat, Ahmed works hard to prove his loyalty. He explains that the sympathy shown in the translation transcripts with his fellow Muslims is not real; it is used as a tactic to win their confidence and speak the truth. That is, he deceives them into believing that he is rather sympathetic with them and the harm they do to the United States is quite justifiable because of what America has been doing to Muslims. However, and though he could be honest in conducting his investigation, his superiors who read the translations and evaluate them have come to believe that he is not loyal enough to America and that he is probably not telling the truth.

His superiors have noticed that during his interrogation of suspects and throughout his stay on the camp he has not exhibited enough behavior to make him fully American. For example, he does not socialize with his fellow American colleagues at the camp mess, or does not take showers in the locker rooms, a practice which is common in American gyms. He did not show up to view the Super Bowl, which is considered a national game for Americans. These little incidents and other trivia have made his superiors question his loyalty. This is further enhanced by what his superiors have deduced from the translation dossier that Ahmed has shown sympathy with the Muslim suspects that he has interrogated. Kevin, his boss, tells him:

Let me say something here. (Looks over to check on Samir as he moves Ahmed further away.) I know this is weird. I know things may feel like they're a little drug-induced. A little surreal. But here's the thing about family. In America, son: you leave family-to find family. That's how it works. We're not tribal. We don't do blood feuds. We've evolved. You want to do family, join the mafia. You're part of something bigger here. Which is to say, I do consider you like a son. You've found your family here. Do you understand what I'm telling you? (p. 178) 
This is indeed the crux of El Guindi's plays that deal with identity formation and the situation of immigrants, especially Arabs and Muslims, find themselves in; they are divided between their native culture and identity and their new American identity.

This dilemma is tackled in the second act of Room Languages. In the second act of the play, which is emotionally intense, Ahmed is confronted with his father, Samir, who has been flown into this interrogation base because it is suspected that he has a connection with the leader of an Islamic terrorist group in his neighborhood in America, Imam Al Rawi, who has been collecting donations and money transfers. Ahmed, who deserted his family a long time ago, is surprised that his father is a terrorist suspect and that his loyalty is put to the test. Samir is surprised to find his son at such a place. Ironically, Samir is overjoyed that his son is working for the US government. During the interrogation, it becomes clear that Ahmed used to be ashamed of his father and the way he dressed and spoke with a foreign accent when he was a pupil at school. As he grew up, Ahmed left his family and wanted to live an independent life on his own. Hence, the government has hired him as a translator and interrogator. Ironically, and despite his extreme vetting of the detainees, Ahmed becomes a suspect himself accused of being sympathetic with Muslim detainees. As he points out, he has shown sympathy with the detainees to gain their confidence and infiltrate them; yet, his superiors do not believe that he is telling the truth. Kevin, who is African America, had a similar experience during the Civil Rights Movement. He says that the government employed him to infiltrate his fellow African-American citizens and that one of the tactics he used was to show sympathy and understanding for what they were doing to penetrate their ranks. Kevin was never punished or suspected for his tactics. Ironically, Ahmed is put under surveillance, perhaps because of his origin as an Arab Egyptian.

Ahmed is surprised to find himself face to face with his father in a situation which becomes a haunting experience for both father and son. Samir was arrested for being accused of having a connection with Imam Al Rawi, probably a leader of a suspect Muslim terrorist group. He was brought to this dark site where Ahmed and his colleague Nasser are working as translators and interrogators of Arab detainees.

The second scene of the play reveals much about Samir, his family, and his past. Denying that he has ever had any connection with Imam Al Rawi or being in knowledge of his terrorist activities, Samir divulges a secret that he has hidden from everybody. To explain the many phone calls with Al Rawi, Samir says that he has had a secret romantic relation with Al Rawi's wife, thus making his son Ahmed never trust him or believe his stories. Ironically, Samir is ready to cooperate and admit any accusation if this will help his son in his career. Indeed, the interrogation takes us back and forth to review Samir's life long before he immigrated to the States and his disappointment that he has not found the promises of the American Dream. At the same time, Ahmed is working hard to prove to his superiors that he is loyal to his country, the United States, and that his sympathy does not hinder him from doing his job the best he can.

In line with the interrogation protocols and compliance with the orders of his supervisor, Ahmed asks his father to undress, an act which Arabs consider as most shameful and humiliating. Samir complies with the order and begins to take off his clothes although his son asks him to stop it. At this point, and towards the end of the interrogation, Kevin enters and asks Nasser to escort Samir outside the room. Convinced that Ahmed's loyalty is still in doubt, Kevin asks Ahmed to go inside the scuba suit to be isolated. It seems the authorities use this technique to make a suspect reexamine his loyalty. Samir is brought back, and he is flabbergasted to see his son put in the isolation suit. The play ends with Samir's monologue reminiscing about his old days in Egypt and the time when Ahmed was a child; he remembers his dreams to immigrate to the United States to give his son an opportunity for a better future. In this play, El Guindi suggests that the dreams of immigrants 
to make it in the United States have been smashed by the 9/11 terrorist attack and the profiling and persecutions of Arab Americans afterwards.

Throughout the play, El Guindi makes his audience aware of the torture tools often used upon the detainees. The cart, which is covered with a piece of cloth, contains, among other things, torture tools:

Kevin exits. Samir approaches the food cart.

Samir ... He is about to eat but stops. He looks over to the cloth-covered cart. He puts the pita down, goes to that cart and removes the cloth, revealing several metal instruments and assorted objects. This includes the baseball-in-stock, pliers, and a closed carton of milk. (p.179)

Upon seeing the tools, Samir asks: This is what you use on prisoners? Ahmed doesn't respond.

Samir: You? ... These are the tools of your work?

Ahmed: We rarely have to go there. It's for show (p.179).

The worst torture applied to the prisoners is to strip during the interrogation. In a revealing conversation with his father, Ahmed ironically and bitterly comments on the dilemma of many Arab Americans who believe in America, but have not been accepted:

\begin{abstract}
Ahmed: Puppy:- He wants me to strip you.-Naked. To humiliate you. To urge you, that way, to tell us what you know. To make you stand on that chair, naked, and, if that doesn't work, he'll bring in a couple of guards to take over. But you know what: you're right: I am being paid well. If that was the goal, your gamble paid off, look at me.

Samir: This is temporary.

Ahmed: No, this is my job. This, right here, is where your journey ended. These are my work tools. This is my country. This is what you brought me to.

Samir: This is just fear on their part. Things will go back to normal soon.

Ahmed: This is normal. This is how we keep the normal going for everyone else. By making sure people like you don't hurt us (pp. 181182).
\end{abstract}

This physical and psychological torture is applied to the political prisoners who are suspected of having a connection with terrorists. As a protocol of the War on Terror, American government agencies have used all sorts of torture on the prisoners to extract information from them. They have never listened to their pleas of innocence; if you are unlucky at the time of the paranoia, then you will probably be incarcerated indefinitely and subjected to all sorts of torture.

As shown in Language Rooms, Samir has immigrated to America by winning the lottery, hoping that his family would have a better future than it is the case in Egypt. However, Samir is obviously disappointed. Back in Egypt, he was working as an engineer, but here in the United States, he was working at a grocery store. This is something also noticed in Ten Acrobats in an Amazing Leap of Faith, in which an Egyptian family is struggling to be assimilated within American society (Kan, 2008). Like Samir, Kamal, the father of the family, immigrated to America long ago, but he is unhappy being a carpet salesman, and he feels nostalgic for his old days in 
Egypt. In Language Rooms as in Ten Acrobats in an Amazing Leap of Faith, the first generation of immigrants like Kamal and Samir are not quite settled in America, and they feel disappointed for not achieving the promises of the American Dream. However, they stay on for the sake of their children as they realize that they have begun to lose them. This is evident in the case of Samir and his son Ahmed. There has been an estrangement between them, for Ahmed is becoming fully immersed in American culture and feels ashamed of his father. Kamal's son, Tawfiq, begins to lose faith in Islam and to the disappointment of his father, he tells him that he will not go to the mosque anymore or practice his religious rituals as he used to do.

El Guindi has depicted in his plays, Back of the Throat and Language Rooms, that Arab Americans are often arrested and tortured both physically and psychologically to make them speak of terrorist crimes that they have never committed. Khaled is humiliated and traumatized in Back of the Throat, and his privacy has been invaded on the false assumption that he has some sort of a liaison with suspicious people. There is no material evidence that he has such a connection and his repeated denials are of no avail. However, the two government agents have pushed him to the edge and physically beaten him. Worse than that, Khaled is forced to take off his pants and Bartlett peeps into his peckers looking for some cryptic message that could be hidden in there. This is a mortifying and humiliating experience to which Khaled is subjected. Similarly, Samir in Language Rooms is physically and psychologically tortured and subjected to the same humiliations that Khaled perpetrated upon, ironically by his own son, Ahmed, who obviously works for the CIA.

\section{Stereotypes of Arabs in the Cinema and Theatre}

Hollywood cinema has traditionally depicted Arabs as villains and terrorists. Jack G. Shaheen (2014) examines the vilification of Arabs in his seminal book Reel Bad Arabs: How Hollywood Vilifies a People in which he has meticulously analyzed the stereotypes of Arabs in dozens of movies released between 1994-2000. El Guindi counters the stereotypes of Arabs and Muslims in the American cinema in his play Jihad Jones and the Kalashnikov Babes. Indeed, in the prefatory "Author's Notes," El Guindi explains his reason for writing this play. "The genesis for this play arose from years of being that Arab kid watching actors of Arab descent taking on these kinds of bad-guy roles. As I would sit there either cringing or enraged at these portrayals, I would think: what on earth persuaded these actors to take these parts" (p. 6). Therefore, El Guindi writes this play, in particular, to write back to the demonization of Arabs in Hollywood movies such as James Cameron's movie True Lies (1994), Edward Zwick's movie The Siege (1998) and others in which Arabs are depicted as terrorists and despicable people (Elayan, 1994).

The play is a hilarious comedy that exposes the absurdity of assigning evil and terrorist parts only to Arabs. The play is about an Arab-American actor named Ashraf who has just been successful in playing the role of Shakespeare's Hamlet in the theatre. He makes two hundred dollars weekly, a sum that is barely enough to pay his living expenses. Luck knocks at his door when his performance of Hamlet is admired by a renowned Hollywood cinema director, Julius Steele, who wants to produce a movie in which an American family is besieged and attacked by Arab terrorists.

The play is set at the offices of Barry, Ashraf's agent, who is so jubilant because this movie deal will make him so much money. Barry gives Ashraf the script of the movie and tells him he must be thankful for this golden opportunity because he will be playing with a Hollywood starlet, Cassandra Shapely. The story of the movie, which is partly rehearsed on the stage, is about the siege of an American family that has been attacked by an Arab terrorist named Mohammed who commits atrocities on the family and tries to rape their daughter, the 19-year old Sherry. Notice that the name of all Arab/Muslim terrorists in American movies is Mohammed, suggesting that the 
Prophet of Islam is the founder of Islamic terrorism. Indeed, the Prophet Mohammed has always been misrepresented as a terrorist strapped with explosive belts to murder Christians and children. One may well remember the French magazine Charlie Hebdo and its cartoons that mocked the Prophet Mohammed on 9 February 2016. The publication of the cartoons led to a wide condemnation by Muslim organizations in France, and this probably caused the terrorist attack on the magazine offices and the massacre of many people in January 2015.

El Guindi's play presents several issues simultaneously. First, it is a play within a play; that is, the frame play which is being unfolded is about making a deal with the Arab American actor Ashraf to play the lead role in a movie which is partly stage-rehearsed during the discussion of the deal. This involves Barry, the cinema agent, who has recruited Ashraf to play in this new movie, and in the course of the play, he tries to convince Ashraf to accept the offer telling Ashraf that he must be thankful for this opportunity because it will make him millions. Ashraf should be grateful to have this opportunity because he will be playing with the famous Hollywood starlet Cassandra whose nude picture appears in The Playboy magazine. Importantly the film will be directed by a famous director, Julius Steele. The question is whether Ashraf will accept working in this movie which reinforces the stereotypes of Arabs and Muslims and demonizes Arabs as evil thugs.

The second issue is the inset play; that is, the script of the movie, which Ashraf will be playing with Cassandra. The script, as mentioned earlier, is being partly rehearsed on the stage. At the beginning, Ashraf hesitates to be part of the movie because it demonizes his own people and culture and in a sense, makes everybody hates Arabs.

Ashraf: Tell me, please, What is Jeffersonian about the opening scene of this film. Where you have Arab thugs bursting in on an American Thanksgiving dinner. Where the first thing Mohammed does after wrenching the grandmother's neck is stick his hand into the turkey, scoop out all the stuffing, throws it, and then forces the entire family to lick it off the floor. Paying special attention to the nubile teenage daughter as she bends down to do it (p. 21).

To convince Ashraf to accept the role, Barry tells Ashraf that the movie is a satire that intends to ridicule American family: "The family! Of course, it's the family.... The overconsumption, the excesses, the mindless gluttony. A family with enough food on their table to feed hundreds. ... The whole film is an indictment of that ( $\mathrm{p}$. 23).

Of course, Ashraf is not convinced of Barry's interpretation, for he later raises the theme of the film and whether it is a satire of the American family with the film director Julius Steele, who, in turn, is quite surprised at this suggestion. Julius Steele sums up the action of the film as follows:

Mohammed and the others have just tied the family up. They've helped themselves to the dinner. His hands are all greasy, if you will, if you want to focus on something tactile, to ground yourself. Also, smell. Smell is important. She talks about him smelling, what does that mean? He's dragged Sherry away from her family. She's broken loose and run into the bedroom. He chases her. She tries to lock it; he breaks in (p. 37). 
After that Ashraf and Cassandra rehearse the script to the full applause of Barry, Julius Steele, Cassandra and the secretary, Peggy. Ashraf has done slapsticks and gags such as picking a handgun as a stage business and wrapping himself with a keffiyeh and speaking with a Middle Eastern accent. The film director appreciates Ashraf's acting and tells him that it is going to be a box-office success.

However, Ashraf has an awakening at this moment. He has to decide whether to play in the movie, which obviously condemns Arabs and the Arab culture, for the sake of fame, glamour and money or decline to participate into a masquerade of Arab culture.

Julius: You think it's full of stereotypes?

Ashraf: Please don't say that like I've gone mad. You've got to see that.

This movie is the equivalent of me picking up this gun (picks up the gun) and threatening everyone in this room.

Barry: Oh, God, meltdown.

Ashraf: That's how deadly this stuff is in the long run. It blows a hole in the minds of the audience until they actually think this garbage is true. That people of my ethnic persuasion are naturally violent and prone to blow up at the slightest thing. That we're vicious and a menace to decent people everywhere (p. 45).

The debates among Ashraf, Barry, and Julius as to whether the movie is mocking Arabs and Muslims, and whether it is in any ways perpetuating racial profiling and demonizing the other, i.e., Arabs, is reminiscent of the debates ensuing after releasing movies that defame Arabs in Hollywood movies (Reid, 2013). El Guindi addresses this in his comedy Jihad Jones in which he notes that villainous roles in the theatre and cinema scripts that denigrate Arab culture and demonize Muslims are often allocated to Arab-American actors. They are being discriminated against in the world of entertainment, and the roles that are readily available for them are dealing with Arab villains and terrorists. Ashraf decides not to accept the offer. The end of the play shows Barry begging Ashraf to accept the offer. Barry humiliates himself in a farcical manner for the sake of money.

\section{Acculturation and Clash of Cultures}

El Guindi persistently pursues Arab stereotypes in almost all his plays. For example, in his play Our Enemies: Lively Scenes of Love and Combat, El Guindi highlights the stereotypes of Arabs in American media, namely, television, radio, and the publishing industry. In this play, El Guindi puts different Arab American characters on the stage who are facing a myriad of problems in their search to form a new American identity and shed off their genuine Arab identity. Set against a background of stereotypical notions about Arabs and people of Middle Eastern origin, this play might be considered, in particular, as a discussion drama similar to the plays of Bernard Shaw. El Guindi treats several controversial issues relating to the Arab-American community in this play. First, the play portrays the media coverage of Arabs and Islam in the context of Islamophobia and what one may term Arabophobia, that is, the fear of Arabs because they are associated with terrorism and backwardness. The media in the play are represented by three outlets: radio, 
television and publishers. Obviously, El Guindi suggests that the media are propagating stereotypes of Arabs and Muslims. Arab Americans appear in TV and radio talk show programs to speak about issues concerning the clash of civilizations and Islam.

The second topic the play deals with is the social relations between Arab Americans. The play suggests that Arab Americans are not in harmony with each other, and there is always infighting between them (Radwan, 2018). This is clearly demonstrated in the conflict between the main Arab characters: Gamal and Mohsen, Gamal and Sheikh Alfani and Gamal and Noor. For example, Gamal thinks that Alfani, Mohsen, and Noor are selling themselves to the media and that each in his or her way is adding salt to the wound in terms of tarnishing the public image of Arabs and Muslims. Confronting Sheikh Alfani on the streets, Gamal insults the man for what he has said in the media: "Don't you see how you're being used? They love you for all the reasons that make most of us Muslims cringe" (p. 100).

Gamal is a novice writer who is trying to publish a novel, but he fails probably because his story does not align with the public image of Arabs in American media. Gamal lashes at his American host society and his fellow Arabs because he could not get his novel published. He is embittered by the television talk shows of Mohsen, who is a successful Arab writer, and who frequently appears on television to talk about Arab culture and Islam in a manner that makes him a media favorite. He thinks that Mohsen is contributing to the distortion of the public image of Arabs and Muslims. Therefore, he tries to insult him. At the beginning of the play, Mohsen is at the television studio getting prepared for an interview. During the smoking break that Earl, the TV director is taking, and just minutes before the beginning of the show, Gamal sneaks into the studio disguised as the make-up man who comes to do Mohsen's makeup. Mohsen does not recognize Gamal as an Arab because he (like Mohsen) speaks with an American accent so that he is not recognized as an Arab. He rouges Mohsen's face in a clownish manner and draws on his forehead the word "whore".

Likewise, Gamal is angry at Sheikh Alfani, the Muslim cleric and the Imam of the only mosque in town, who is a frequent guest on radio and television talk shows to talk about Islam. It seems that Alfani's talks echo the American political discourse on Islam. He always presents Islam from the viewpoint of the American government and presents an ameliorated image of Islam that aligns with the American concept of what Islam should be. For instance, on a radio talk show, Alfani engages in interfaith dialogue with a Christian priest and a rabbi. When asked about the attitude of Islam towards homosexuality and gays, the priest and the rabbi kept silent. Alfani ventures to say that being gay is an "abomination"- a statement that would probably harden the viewers' attitude toward Islam and dub it as a religion that lacks tolerance and does not accept others. This interview, in particular, angered Gamal who decides to insult Alfani. Gamal awaits Alfani on the street, and he stops him for a moment:

Gamal: Like today: on the radio, when you were asked about gays. All three guests were asked the same question. And what did the priest and the rabbi say? Nothing. They danced around the question and even made it seem like it was a no-issue. "Hey, our religion never had a problem with gays." Only you used the word "abomination." They understood what they had to say, but you just had to spew out your garbage" (pp. 100-101).

Gamal shoves the birthday cake that he has bought to celebrate his girlfriend's birthday into Alfani's face in front of Alfani's son, Hani. Later, towards the end of the play, Hani will take 
revenge on Gamal for insulting his father; the play ends violently with Hani stabbing Gamal in the stomach.

El Guind presents all four Arab American characters in the play as lacking depth and genuine character. Mohsen has turned on his own people and become completely Americanized. He talks boldly against his native culture, people, and country of origin, which is Egypt. He is deeply immersed in the American way of life, and he drinks alcohol. He sleeps with women, and is rather unabashed about sexual freedom. We see him in an almost pornographic situation in Act Two, Scene Two, sleeping with the only Arab character in the play, Noor. He adopts a new culture and identity, which is opposite and even inimical to his native culture. Gamal believes that Mohsen has betrayed his own people being immersed into the glamour of what America has to offer.

Noor, the only Arab woman in the play, has as well betrayed her own people and culture. She has abandoned her parents, who went back to Egypt and decided to live on her own in the United States. Very much like Mohsen, Noor is writing a novel that she is trying to get it published. Olivia tells her that this is not the kind of novel that will be a bestseller. She has to write a novel that is full of zest based on her experience as a free Arab immigrant woman living in America. Olivia gives Noor advice on how to write a publishable novel: "My point is. I am not sure these are your typical concerns of a young American woman. Perhaps a young Americanized woman. A young immigrant woman is trying to strike out her own and break away from her traditions. That would be interesting. I'd love to read about that. That would be a window into a world people are curious about" (p. 94).

Though at the beginning Noor does resist the idea, later in Act One, Scene Four, she is editing her novel and changing the Latin names of her characters into Arabic names. The novel is probably based on her experience in the United States, for the novel talks about an Arab immigrant woman who has abandoned her family and folks for the sensual pleasures of life that America offers. Having rewritten the novel from the point of view of her publisher Russel and her editor Olivia, Noor will be accepted by the media, and she will be invited to appear on television talk shows and goes on publicity tours.

Noor is similar to Mohsen in embracing the American culture and rejecting her family traditions and Islam. As it is mentioned earlier, she lives on her own, and she has a boyfriend, Gamal. She has no qualms about drinking alcohol and sleeping with men other than her boyfriend. Despite her quarrel with Mohsen in the party that Russel hosted in Act One, showing her prudish nature by throwing the martini on Mohsen's face for being free with her, we see them in bed together in her apartment in Act Two.

She dares to confront Mohsen as follows: "the only reason I'm screwing you is because the batteries have died out on this baby, (holds up a vibrator) And my boyfriend happens to be out of town" (p. 125).The confrontation between the triangle of lovers, Mohsen, Noor and Gamal in the same scene shows how degenerated that these Arabs have become and that these Arabs have deserted their own native culture in favor of becoming fake Americans. However, they go to the extreme in their perception of what America stands for. America cannot be boiled down to sex, booze, and immorality. El Guindi is probably critical of this very narrow perception of American values; these Arabs have distorted the image of Arabs and Islam and contributed to the stereotypical notions that Arabs are crazed about sex and sensual pleasures.

El Guindi presents Arab Americans as rather violent and narrow-minded in his play. We have seen some examples of their violence throughout the play. Early in the play, Gamal has vented his anger at Mohsen when he paints his face and writes the word whore on his forehead. Gamal also insults Sheikh Alfani on the street and violently shoves the cake into his face while his son, Hani, is watching. As a result, Hani gets angry, and he decides to take revenge on Gamal. Hani 
always asks his father to talk to a person named Munir for protection. Upon his return from his trip to Egypt, Hani ambushes Gamal and plunges his knife into his stomach. In fact, the play ends with two violent scenes; Alfani's mosque, where he is Imam, is burned to the ground, including the family Koran of Alfanis.

The identity of the culprit is never known in the play. The police determine that it is arson. Hani thinks the arsonist must be Gamal, and there is a good reason to accuse Gamal of the arson because of the animosity that he has had with Sheikh Alfani. Dazed at Hani's act of violence, Gamal tries to be apologetic for insulting Sheikh Alfani, and he categorically denies that he burned the mosque. The play ends at this note of violence perpetrated by an Arab American character, a US-born citizen and the son of an immigrant. In post- 9/11 American culture, this action reinforces the stereotypes of Arabs as violent and aggressively driven by a passion for revenge.

El Guindi shows that Arab Middle Eastern countries are portrayed rather negatively in American media. Using cinematic techniques and epic theatre features such as flashbacks, and TV screens, El Guindi shows Arab countries in turmoil and upheaval. Throughout the play, the audiences are made aware of the unrest and violence taking place in the Middle East. This is shown through the images of demonstrations on the screens. Understandably, because scenes of the play take place at a television studio, it is, therefore, justifiable to see screens all over the studio. But to have demonstrations and violent images of Arabs on these screens is meant to suggest that these remote countries are facing protests and riots. By doing so, El Gundi is probably enhancing the public image of Arab countries and people as living in social and political unrest. Besides, El Guindi draws up an image of Egypt as opposed to the United States. The country is portrayed as backward and uncivilized; thus, the dramatist is inadvertently reinforcing the stereotypes of Egypt that are commonly found in American media.

El Guindi postulates that stereotypes of Arabs and Muslims are deeply rooted in American culture. Media venues such as television, radio and publishing agencies reinforce these stereotypes. At the same time, someone living in the United States will never be accepted unless he or she follows the paradigms of the social character that the hegemonic culture has set up for him or her. This is clearly demonstrated through the successes that Mohsen, Noor, and Sheikh Alfani have. Therefore, El Guindi presents the power of the media in shaping public opinion towards the "other". Even the version of Islam that Sheikh Alfani is representing has been stamped by what Americans want it to be.

At the same time, El Guindi critiques Orientalized American attitudes towards the Middle East. For example, Earl says that he likes the Orient, in this case, the Mediterranean culture, in a rather condescending manner. This is shown in Earl's comment on the health habits of the people of the Middle East.

Earl: Time enough for a smoke. Care to join me?

Mohsen: No, thank you. I gave it up.

Earl: What d'you do that for? People are getting too prissy about their

health. The one thing I liked about the Middle-East was that people

didn't seem as hung up on health crap as we are here.

Mohsen: I'm afraid health consciousness is seeping in even among the

Bedouins and sheep herders.

Earl: Sorry to hear that. The problem with Westernization going global is there's no escaping the West now. Even a West cheerleader like me needs to escape it now and again (p. 90). 
El Guindi has developed the theme of Our Enemies further in his play Threesome. He presents in this play three characters: Leila and Rashid, both Arab (Egyptian) Americans and Doug, a white American. The play consists of two acts. In the first act, Leila has invited her boyfriend Rashid and Doug to have a sexual experience together, a threesome, in which she wants to completely free her body from any consciousness and live the experience and have a good time. She has invited the two gentlemen to her apartment in an unidentified American city, and the whole act is set in her bed with each character is almost naked or utterly naked like Doug. The act is farcical and comically hilarious where we see the three characters do all kinds of gigs and sexual jokes. However, no sexual intercourse is going on, and the act ends with Doug ordering a pizza from the bathroom, and finally, teased by Rashid, he decides to leave (Stack, 2015). During the act, Doug is revealed a photographer working for a certain publisher. Likewise, Rashid is a photographer. Each of them thinks that he is going to do the cover photographs for Leila's book about her experiences during the 2011 Egyptian Revolution, which was accepted for publication by a US publisher.

However, it is the second act that highlights the stereotypes of Arabs that El Guindi in this play is critiquing and ridiculing. The second act is set at Doug's studio, where we find him preparing the scene to take shots for Leila's book cover. El Guindi suggests that the West represented here by Doug is fantasizing the Orient, setting it apart from the West. In other words, when Doug thinks of representing the Orient in his screenshots for Leila's book he is deeply influenced by the stereotypical depiction of the Orient that we often find in travel books and Orientalist writings. Indeed, this whole act confirms Said's critique of the Orientalist discourse in which the Orient is "reimagined" and reproduced for the sake of hegemony (1979). The stage setting of the act represents the Orient as rather exotic and far-fetched commensurate with Orientalist representations. The tropes of the Orient include the abaya, the veil, the hookah, and other props that Doug is using in creating an exotic Oriental setting for his photographs of Leila's book.

Leila is Americanized, and she has adopted a radical version of feminism. In the name of freedom and to prove that she has no objection to having sex in her apartment with two men together, she has invited Doug along with her boyfriend Rashid to go through the threesome experience as seen in the first act of the play. However, Leila strongly rejects the way Doug has reimagined the Orient. A debate between Leila and Doug on the Western conception of the Arab and Muslim woman ensues. Leila points out that wearing the abaya and veil are matters of choice, and they do not necessarily indicate the repression of women in the Arab world. However, Doug believes that such photographic portrayals of the Orient would entice the American reader and increase the book sales.

We realize that Doug, like Carl in Back of the Throat, had been in an Arab country, probably Iraq during the invasion of that country accompanying the American troops. He narrates a sexual adventure that he had experienced with a poor Arab woman who lured him into having sex with her to get money, probably to buy food for her children. Though he regrets his sexual encounter with the Arab woman, he still cherishes the experience. In his narrative at the end of the play that occupies almost two pages, he graphically narrates the incident without any consideration for Leila's feelings as an Arab woman. Leila is infuriated at his callousness for taking advantage of the poverty of the Arab woman. Free as she is, Leila gets very angry at the stereotypical depiction of the Arab woman and the Arab world at large. She slaps Doug on the face, and angrily tears her $a b a y a$ and veil to complete nakedness to protest against Doug's representation of the Arab woman and the story of the Arab woman he had sex with during his coverage of the war in an Arab country. In the stage directions of this incident El Guindi suggests that Leila's tearing her abaya to utter 
nakedness should be seen as an act of challenge and defiance, an expression of her empowerment and fearlessness (p. 309).

As already suggested, Threesome is a sequel to Our Enemies of some sort. The playwright uses the 2011 Egyptian Revolution and the Arab Spring as backgrounds in the two plays (Najjar, 2015, pp. 554-556). For example, in Our Enemies the TV screens in the studio show demonstrations and riots taking place in an Arab country, probably Egypt. In Threesome, Leila and Rashid went back to Egypt to participate in the Revolution. Leila's book deals with her experience during the Revolution. Though the book details are never disclosed, we understand that she was assaulted and raped by police authorities. The book was accepted by a US publisher who has assigned Doug to provide photographs for the cover of the book. Rashid, Leila's boyfriend, thinks the publisher will pick him to take the photos for the book cover. To his surprise he realizes in Act Two that Doug has been picked up by the publisher to do the job; moreover, Rashid has had no chance to read the book whereas Doug has a copy of the book, and has read most of it. That is why we find Doug setting the stage to take photographs of Leila in the second act. Being immersed in the Oriental discourse, Doug has set up an exotic setting for the pictures, something that has upset Leila and made her angry at Doug's stereotypes of the Orient in general and the Arab woman in particular.

El Guindi critiques Orientalism and the depiction of the Arab world as exotic and fantastical. Like Our Enemies, we have an Arab American woman who is radically liberal and embracing Western values especially as they concern sexual freedom and the politics of gender. Leila in Threesome is more liberal than Noor in Our Enemies. Leila is radically a Westernized woman, a kind of an avant-garde feminist who rejects all Arab traditions and values. Like Noor, Leila wrote a book about her experience during the Egyptian Revolution of 2011, which she tries to publish in the United States. To do so she includes in the book materials that would appeal to a US reader and feed his/her imagination about the exotic Orient. Noor, in Our Enemies, has abandoned her family and Arab traditions and become deeply immersed in American life just to be accepted. She has drastically modified her novel following the suggestions of her publisher to be accepted by the American publishing media. Likewise, Leila has freed herself from all her Arab traditions and, she become extremely Westernized. Noor has a boyfriend, Gamal, and she drinks and sleeps with Mohsen in contravention of her moral values. Similarly, Leila has a boyfriend, and she invites Doug to have a threesome just for the novelty of the experience and to exercise her freedom and empowerment.

Threesome is a dark comedy in which El Guindi aims to achieve many goals. First, El Guindi criticizes Arab Americans who have sold themselves to the American media just to be recognized. We have seen this in Our Enemies especially when Mohsen, Noor and Sheikh Al Fani do what they could to please the American media and reinforce the common stereotypes of Arabs and Moslems. Leila and Rashid do precisely the same. Leila, in particular, has shed off the trappings of her native culture and Muslim values to be a completely free woman though she ironically defends the abaya and the veil. Second, El Guindi in both Our Enemies and Threesome shows that the American publishing media will agree to publish materials that denigrate the Arab world and demonize Arabs.

The book that Leila wrote is a case in point. Though details of the book are not revealed, there is a suggestion that Leila was sexually harassed and raped multiple times by government agents during the demonstrations. Leila has written graphically about such assaults to satiate the thirst of readers for such sexual escapades. Third, the publisher of the book hires Doug to take photos of Leila as a stereotypical Oriental woman, wearing the abaya and the veil amid an Oriental exotic setting to increase the sales of the book. It is true that Leila finally rebels against this kind of exotic representation of the Orient, but she is driven by Doug's narrative of his sexual fantasy 
with the Arab woman. The story that he tells about his sexual encounter with this woman is similar to the stories told by Western travellers to the Orient, Egypt in particular, mentioned in Said's Orientalism (pp. 188-190). Fourth, both Our Enemies and Threesome have as their background the Arab Spring and the Egyptian Revolution.

\section{Conclusion}

Arab-American playwrights and performers delineate the richness and diversity of their experience as Arab-American writers in their plays and theatre. Though Arab-American dramatists and performers are relative new comers to the literary arena in the United States, their contributions have made their experience as hyphenated Arab Americans visible in American drama and theatre. They write about issues that arise from their genuine experience as Arab Americans. ArabAmerican playwrights and performers have one thing in common; they all suffer the backlash of the 9/11, and the consequences of the War on Terror. One major issue that almost all ArabAmerican writers have dealt with is the stereotypes of Arabs and Muslims and the misrepresentations of Islam as hostile to the Western way of life. Therefore Arab-American dramatists and performers resist such stereotypes and assert that they are American citizens who are proud of their Arab heritage and culture. Using the stage as a platform or political arena to voice their concerns and expose the stereotypical falsehoods attached to Arabs and Muslims, ArabAmerican writers raise in their works the most pressing problems that directly affect their existence and identity in the United, and address the forces that impact their status as American citizens.

Arab-American playwrights and performers have introduced Arab people and culture to American audiences, and therefore they help dispel the stereotypes that have been attached to Arabs and Muslims via media outlets and politics. They have generally drawn up positive images of Arabs and countered the common stereotypes of Arabs and Muslims prevalent in Orientalist discourse. The paper has focused on El Guindi because he is the most prolific Arab American dramatist who has dealt with diverse aspects of the Arab-American identity formation in his plays. El Guindi's plays are interrelated thematically because he tries to counter in almost all of them the stereotypes of Arabs in American media outlets. He tackles in his plays a wide range of topics and issues relating to racial profiling and persecution, the hybrid status of Arab Americans in the United States, and their struggle to cope with their new host culture and society. In general, El Guindi's plays spotlight the hardships and challenges that beset Arab immigrants in their attempt to assimilate into the mainstream culture of American society. El Guindi gives voice to the silent Arab-American citizens by humanizing them in terms of their identity and experience. In short, El Guindi becomes the voice of Arab Americans because he has espoused almost all issues relating to the identity formation of Arab Americans and countered the stereotypes attributed to Arabs and Muslims caused by the fallouts of 9/11 in his drama and theatre.

\section{References}

Ali, R. (2017). In response to narratives of stereotypes: Arab American playwrights reclaim and fortify Arab American representation. Gramma: Journal of Theory and Criticism, 24, 8191. https://doi.org/10.26262/gramma.v24i0.6119

Alqahtani, S. M. (2018). Post-9/11 Arab American drama: Voices of resistance in Back of the Throat and Browntown. Journal of Muslim Minority Affairs, 38(3), 392-408. https://doi.org/10.1080/13602004.2018.1502403 
Alsultany, Evelyn (2012). Arabs and Muslims in the Media: Race and Representation after 9/11. New York University Press.

Arjana, S. R. (2015). Muslims in the Western imagination. Oxford University Press.

Bakalian, A. \& Bozorgmehr, M. (2009). Backlash 9/11: Middle Eastern and Muslim Americans respond. University of California Press. https://www.jstor.org/stable/10.1525/j.ctt1pngn5

Basiouny, D., \& Carlson, M. (2009). Current trends in Arab-American performance. In S. Jestrovic \& Y. Meerzon (Eds.), Performance, exile and 'America': Studies in international performance (pp. 208-219). Palgrave Macmillan. https://doi.org/10.1057/9780230250703

Bauböck, Rainer \& Thomas Faist (eds.) (2010). Diaspora and Transnationalism: Concepts, Theories and Method. Amsterdam University Press. DOI: 10.5117/9789089642387

Cameron, James (Director). (1994). True Lies [Film]. Lightstorm Entertainment.

Daniel, N. (2009). Islam and the west: The making of an image. Oneworld Publications.

Dogutas, A. (2020). Effectiveness of School and Family on Enculturation: Perceptions of Students. American Journal of Qualitative Research, 4(3), 8391. https://doi.org/10.29333/ajqr/8559

El Guindi, Y. (2009). Ten Acrobats in an Amazing Leap of Faith. In H. Hill \& D. Amin (Eds.), Salaam. Peace: An Anthology of Middle Eastern-American Drama. Theater Communications Group.

El Guindi, Y. (2014a). Back of the throat. Dramatists Play Service Inc.

El Guindi, Y. (2014b). Jihad Jones and the Kalashnikov babes. Dramatists Play Service, Inc.

El Guindi, Y. (2014c). Our Enemies: Lively Scenes of Love and Combat. In M. M. Najjar (Ed.), Four Arab American plays. McFarland and Company, Inc., Publishers.

El Guindi, Y. (2019a). Language Rooms. In M. M. Najjar (Ed.), The Selected Works of Yussef El Guindi. Methuen Drama.

El Guindi, Y. (2019b). Rosencrantz and Guildenstern meet Abdallah and Ahmed: Musings about Arabs and Muslims in American theatre. In M. M. Najjar (Ed.), The selected works of Yussef El Guindi (pp.311-318). Methuen Drama.

El Guindi, Y. (2019c). Threesome. In M. M. Najjar (Ed.), The selected works of Yussef El Guindi (pp. 255-309). Methuen Drama.

Elayan, Y. (2005). Stereotypes of Arab and Arab-Americans presented in Hollywood movies released during 1994 to 2000 [Master's thesis, East Tennessee State University]. Electronic Theses and Dissertations. https://dc.etsu.edu/etd/1003

Fadda-Conrey, C. (2014). Contemporary Arab-American literature: Transnational reconfigurations of citizenship and belonging. New York University Press.

Hassan, W. (2011). Immigrant narratives: Orientalism and cultural translation in Arab American and Arab British literature. Oxford University Press.

Hill, H. (2009). New threads. In H. Hill \& D. Amin (Eds.), Salaam. Peace: An anthology of Middle Eastern-American drama (pp. xiii-xxxiv). Theatre Communication Project.

Kan, A. E.-V. (2008). Amazing acrobatics of language: The theatre of Yussef El Guindi. American Studies Journal, 52, 1-36. https://doi.org/10.18422/52-09

Keniston, A. \& Quinn, J. F. (Eds.). (2008). Literature after 9/11. Routledge.

Lacko, I. (2013, September 5-6). Freedom stuck in the throat: Yussef El Guindi's Back of the Throat through the prisms of an individual conflict and a polarized society. In R. Trušník, R. Trušník, G. J. Bell, \& K. Nemčoková (Eds.), Proceedings of the fifth international conference in humanities, Zlin, Czech Republic. http://conference.uaa.utb.cz/tp2013/ From Theory To Practice2013.pdf\# page $=257$ 
Majaj, L. S. (2008). Arab-American literature: Origins and developments. American Studies Journal, 52, 1-12. https://doi.org/10.18422/52-2

Mohammed, A. S. M. (2011). Exacerbation of panic onstage: Ethnic problems and human rights violations in Yussef El Guindi's Back of the Throat (2006). Studies in Literature and Language, 3(3), 165-173. https://dx.doi.org/10.3968/n

Najjar, M. (2014, September). Writing from the hyphen: Arab-American playwrights struggle with identity in the post-9/11 world. http://www.silkroadrising.org.news/writing-from-thehyphen-arab-american-playwrights-struggle-with-identity-in-the-post-911-world

Najjar, M. (2015a). Arab American drama, film and performance: A critical study, 1908 to the present. McFarland and Company, Inc., Publishers.

Najjar, M. (2015b, October). Threesome by Yussef El Guindi (Review). Theatre Journal, 76(3), 554-556. https://doi.org/10. 1353/tj.2015.0088

Radwan, R. R. M. (2018). Enemies and nearby: The violent encounter among Arab Americans in Yussef El Guindi's Our Enemies. Journal of Scientific Research in Arts, 4, 1-20.

Reid, J. W. (2013, October). Hollywood representations of Arab terrorism and counter-terrorism, 1991-2011 [Master's thesis, The University of Adelaide]. The University of Adelaide digital archieve. dspace/bitstream/2440/85040/8/02whole.pdf

https://digital.library.adelaide.edu.au/

Said, E. (1979). Orientalism. Vintage Books.

Salaita, S. (2007). Arab American literary fictions, cultures, and politics. Palgrave Macmillan.

Shaheen, J. G. (2014). Reel bad Arabs: How Hollywood vilifies a people. Olive Branch Press. https://doi.org/10.1177/0002716203588001011

Smith, D. (2006, February 11). For Arab-American playwrights, a sense of purpose. The New York Times. https://www.nytimes.com/2006/02/11/theater/newsandfeatures/for-arabamericanplaywrights-a-sense-of-purpose.html

Stack, L. (2015, July 29). In Yussef El Guindi's plays, personal and political are in bed together. The New York Times. https:/www.nytimes.com/2015/08/02/theater/in-yussef-el-guindisthreesome-personal-and-political-are-in-bed-together.html

Zwick, Edward (Director). (1998). The Siege [Film]. Twin River Productions. 